Article

\title{
Self-Assembly of a 1D Hydrogen-Bonded Polymer from a Hexamethyltetraaza Macrocyclic Nickel(II) Complex and Isophthalic Acid
}

\author{
In-Taek Lim and Ki-Young Choi * \\ Department of Chemistry Education, Kongju National University, Kongju 314-701, Korea; \\ E-Mail: hak124@kongju.ac.kr
}

* Author to whom correspondence should be addressed; E-Mail: kychoi@kongju.ac.kr;

Tel.: +82-41-850-8284; Fax: +82-850-8347.

Received: 3 May 2013; in revised form: 31 May 2013 / Accepted: 3 June 2013 /

Published: 6 June 2013

\begin{abstract}
The compound $\left[\mathrm{Ni}(\mathrm{L})(\text { isoph })_{2}\right][\mathrm{Ni}(\mathrm{L})] \cdot 8 \mathrm{H}_{2} \mathrm{O}(\mathbf{1} ; \mathrm{L}=C$-meso-5,5,7,12,12,14hexamethyl-1,4,8,11-tetraazacyclotetradecane; $\mathrm{H}_{2}$-isoph $=$ isophthalic acid) has been synthesized and structurally characterized. Complex 1 exhibits a geometrically symmetric core with a $\{4 / 6\}$ coordination number set. The coordination environment around the $\mathrm{Ni}(1)$ ion is a distorted octahedron, while the geometry around the four-coordinate $\operatorname{Ni}(2)$ is depicted as square planar in 1D hydrogen-bonded infinite chain. The compound crystallizes in the triclinic system $P-1$ with $a=8.602(2), b=10.684(7), c=16.550(3) \AA, \alpha=91.04(4)$, $\beta=94.09(2), \gamma=111.09(4)^{\circ}, V=1413.9(10) \AA^{3}, Z=1$. The cyclic voltammogram of 1 undergoes one-electron wave corresponding to $\mathrm{Ni}^{\mathrm{iI}} / \mathrm{Ni}^{\mathrm{I}}$ process. The electronic spectra, electrochemical and TGA behavior of the complex are significantly affected by the nature of the hexamethyltetraaza macrocycle and the axial isoph ${ }^{2-}$ ligand.
\end{abstract}

Keywords: 1D hydrogen-bonded polymer; nickel(II) complex; tetraaza macrocycle; isophthalic acid; 4/6 coordination number set

\section{Introduction}

There has been considerable interest in macrocycles with $\mathrm{C}$-alkyl groups on a polyaza macrocyclic ring and their metal complexes because of their structural and chemical properties, which are often 
quite different from those of the corresponding unalkylated macrocyclic ligands [1-18]. The application of polyaza macrocycle precursors in the synthesis of transition metal(II) macrocyclic complexes, stems mainly from their use as models for protein-metal binding sites in biological systems [19], and as selective complexing agents for metal ions [20]. The structures and chemical properties of such complexes are affected by various factors, such as $C$-alkyl groups in the macrocycle and the type and synthetic differences between the axial ligands. For example, the compounds $\left[\mathrm{Ni}(\right.$ cyclam $\left.)(\mathrm{NCO})\left(\mathrm{H}_{2} \mathrm{O}\right)\right]\left(\mathrm{ClO}_{4}\right)($ cyclam $=1,4,8,11$-tetraazacyclotetradecane $)[8]$ and $\left[\mathrm{Ni}(\mathrm{dttd})(\mathrm{NCO})_{2}\right]$ ( $\mathrm{dttd}=3,14$-dimethyl-2,6,13,17-tetraazatricyclo[14,4,0 $\left.0^{1.18}, 0^{7.12}\right]$ docosane) [9] exhibit a distorted octahedral geometry, in which the nickel(II) ion is coordinated by four secondary amines and two nitrogen atoms of the isocynate ligand. However, the complex $\left[\mathrm{Ni}\left(\mathrm{Me}_{4}\right.\right.$ cyclam $\left.)(\mathrm{NCO})\right]\left(\mathrm{ClO}_{4}\right)$ $\left(\mathrm{Me}_{4}\right.$ cyclam $=$ 1,4,8,11-tetramethyl-1,4,8,11-tetraazacyclotetradecane) [8] reveals a distorted square pyramidal geometry, which may be due to the steric constraints of the $\mathrm{Me}_{4}$ cyclam ligand. On the other hand, the octahedral compound $\left[\mathrm{Ni}(\mathrm{L})(\mathrm{OCN})_{1.5}\left(\mathrm{ClO}_{4}\right)_{0.5}\right](\mathrm{L}=C$-meso-5,5,7,12,12,14-hexamethyl1,4,8,11-tetraazacyclotetradecane) [8] presents the peculiarity of the cyanato coordination mode instead of the habitual isocyanate mode. In contrast, the compound $\left[\{\mathrm{Ni}(\mathrm{L} 1)\} 2(\mu-\mathrm{OCN})_{2}\right]\left(\mathrm{ClO}_{4}\right)_{2}(\mathrm{~L} 1$ $=$ DL-5,5,7,12,12,14-hexamethyl-1,4,8,11-tetraazacyclotetradecane) [10] shows that the cyanate ligand acts as an end-to-end bridge with nickel(II) ions in an $\mathrm{NiN}_{5} \mathrm{O}$ octahedral environment. The same synthetic strategy with the azido group leads end-to-end coordination, giving a one-dimensional compound $\left[\left\{\mathrm{Ni}(\mathrm{L})\left(\mu-\mathrm{N}_{3}\right)\right\}_{\mathrm{n}}\right]\left[\mathrm{ClO}_{4}\right]_{\mathrm{n}}[11]$. The different molecular topologies in the complexes may be due to the $\mathrm{C}$-alkyl groups into the macrocycle and different coordination modes of the ligands.

In the present work, we report the preparation and characterization of $\left[\mathrm{Ni}(\mathrm{L})(\text { isoph })_{2}\right][\mathrm{Ni}(\mathrm{L})] \cdot 8 \mathrm{H}_{2} \mathrm{O}$ (1; $\mathrm{L}=$ C-meso -5,5,7,12,12,14-hexamethyl-1,4,8,11-tetraazacyclotetradecane; $\mathrm{H}_{2}$-isoph = isophthalic acid, Figure 1). To evaluate the effect of the hexamethyl tetraaza macrocycle and anionic group, we have investigated the X-ray crystal structure, spectroscopic, and electrochemical properties of the complex.

Figure 1. Structure of macrocycle and isophthalate ligand.

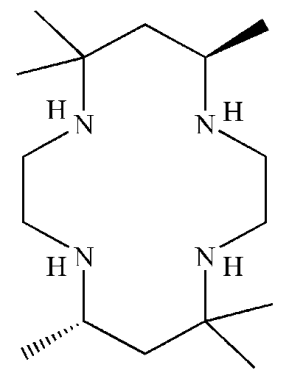

$\mathbf{L}$<smiles>O=C(O)c1cccc(C(=O)O)c1</smiles>

$\mathrm{H}_{2}$-isoph

\section{Results and Discussion}

\subsection{Description of the Structure}

An ORTEP drawing [21] of $\left.[\mathrm{Ni}(\mathrm{L}) \text { (isoph) })_{2}\right][\mathrm{Ni}(\mathrm{L})] \cdot 8 \mathrm{H}_{2} \mathrm{O}(\mathbf{1})$ with the atomic numbering scheme is shown in Figure 2. The selected bond lengths and angles are listed in Table 1. The macrocyclic ligand skeleton of the complex takes the most stable trans-III $(R, R, S, S)$ configuration with two chair six- 
membered and two gauche five-membered chelate rings. The complex has a geometrically symmetric core with a $\{4 / 6\}$ coordination number set. In both structures, the nickel atoms are located at inversion centers. The geometry around the four-coordinate $\mathrm{Ni}(2)$ is depicted as square planar with four secondary amines of the macrocycle, while the coordination environment around the $\mathrm{Ni}(1)$ ion is a distorted octahedron in which nickel ion is coordinated by four secondary amines of the macrocycle and two carboxylate oxygen atoms of the axial isoph ${ }^{2-}$ ligands. Interestingly, the complex $\mathbf{1}$ has different topology compared with the compound $\left\{[\mathrm{Ni}(\mathrm{dttd})(\text { isoph })] \cdot 3 \mathrm{H}_{2} \mathrm{O}\right\}_{\mathrm{n}}[18]$, which exhibits a $1 \mathrm{D}$ coordination polymer with a tetragonally distorted octahedral geometry. This fact may be due to the six methyl groups in the macrocycle, even though the complex $\mathbf{1}$ has the same axial ligand as the compound $\left\{[\mathrm{Ni}(\mathrm{dttd})(\text { isoph })] \cdot 3 \mathrm{H}_{2} \mathrm{O}\right\}_{\mathrm{n}}$. The average $\mathrm{Ni}(1)-\mathrm{N}$ bond distance of $2.070 \AA$ is typical for those of octahedral nickel(II) complexes with 14-membered tetraaza macrocyclic ligands [6-10]. The Ni(1)-O distance of 2.056(6) $\AA$ is shorter than that observed in the related system $\left(\left\{[\mathrm{Ni}(\mathrm{dttd})(\mathrm{tp})] \cdot 2 \mathrm{H}_{2} \mathrm{O}\right\}_{\mathrm{n}}[17]: \mathrm{Ni}-\mathrm{O}=2.116(3) \AA\right.$, where $\mathrm{tp}^{2-}=$ terephthalate), which has a tetragonally distorted octahedral geometry. The average $\mathrm{Ni}(2)-\mathrm{N}$ bond distance of $1.896 \AA$ is in the normal range for square-planar nickel(II) complexes with 14-membered tetraaza macrocycles [11-16]. The N-Ni-N angles of the six-membered chelate rings are larger than those of the five-membered chelate rings. The intermolecular $\mathrm{Ni}(1) \cdots \mathrm{Ni}(2)$ distance is $11.641(8) \AA$, whereas the closest intermolecular $\mathrm{Ni}(1) \cdots \mathrm{Ni}(2)^{\mathrm{i}}$ distance between neighboring strands is 9.607(4) $\AA$. The axial Ni(1)-O(1) bonds are not perpendicular to the $\mathrm{NiN}_{4}$ plane as the $\mathrm{O}_{\text {axial }}-\mathrm{Ni}-\mathrm{N}_{\text {basal }}$ angles ranging from 85.6(3) to $94.4(3)^{\circ}$. The dihedral angles $(\alpha)$ between the plane of the carboxylate group and benzene ring involving $\mathrm{Ni}(1)$ atom are 2.8(2) and $10.5(9)^{\circ}$, respectively. Moreover, the dihedral angle $(\beta)$ between the plane of the carboxylate group and $\mathrm{NiN}_{2} \mathrm{O}_{4}$ plane involving $\mathrm{Ni}(1)$ atom is $14.6(9)^{\circ}$. The $\mathrm{Ni}(1)-\mathrm{O}(1)-\mathrm{C}(9)$ angle and $\mathrm{C}(9)-\mathrm{O}(1)$ distance relative to the isophthalate ligand are $133.7(6)^{\circ}$ and $1.254(11) \AA$, respectively. The deprotonated oxygen $\mathrm{O}(1)$ among the two isoph ${ }^{2-}$ carboxylic groups is coordinated to the metal center. The secondary amine $\mathrm{N}(1)$ of the macrocycle is intramolecular hydrogen bonded to the uncoordinated carboxylic oxygen $\mathrm{O}(2)$ of the isoph ${ }^{2-}$ ligand $\left[\mathrm{N}(1)-\mathrm{H}(1) \cdots \mathrm{O}(2)^{\mathrm{iii}} 2.804(10) \AA, 154.6^{\circ}\right.$; symmetry code (iii) $-\mathrm{x},-\mathrm{y}+1,-\mathrm{z}+1]$. Interestingly, the deprotonated oxygen atoms $\mathrm{O}(3)$ and $\mathrm{O}(4)$ of the isoph ${ }^{2-}$ ligand form intermolecular hydrogen bonds to an adjacent secondary amines $\mathrm{N}(3)$ and $\mathrm{N}(4)$ of the macrocycle involving $\mathrm{Ni}(2)$ atom $\left[\mathrm{N}(3)-\mathrm{H}(3) \cdots \mathrm{O}(4) 2.869(10) \AA, 164.0^{\circ} ; \mathrm{N}(4)-\mathrm{H}(4) \cdots \mathrm{O}(3) 2.841(11) \AA, 157.8^{\circ}\right]$. Furthermore, the water molecules also forms intermolecular hydrogen bonds with uncoordinated carboxylate oxygen atoms $\mathrm{O}(2)$ and $\mathrm{O}(4)$ of the isoph $^{2-}$ ligand $[\mathrm{Ow}(1)-\mathrm{HO}(1) \cdots \mathrm{O}(4) 2.676(11) \AA$, 160(9) ${ }^{\circ}$; $\left.\mathrm{Ow}(2)-\mathrm{HO}(3) \cdots \mathrm{O}(2) 2.734(12) \AA, 163(9)^{\circ}\right]$ and the other water inclusions $[\mathrm{Ow}(2)-\mathrm{HO}(4) \cdots$ Ow(1) 2.706(14) $\AA, 147(11)^{\circ}$; Ow(4)-HO(8) $\cdots$ Ow(1) ${ }^{\text {iv }} 2.829(17) \AA, 145(13)$; symmetry code (iv) $-\mathrm{x}+$ $1,-\mathrm{y},-\mathrm{z}]$. This interaction gives rise to a $1 \mathrm{D}$ hydrogen-bonded polymer (Table 2 and Figure 3 ). 
Figure 2. An ORTEP diagram of $\left[\mathrm{Ni}(\mathrm{L})(\text { isoph })_{2}\right][\mathrm{Ni}(\mathrm{L})] \cdot 8 \mathrm{H}_{2} \mathrm{O}$ (1) with the atom-numbering scheme (30\% probability ellipsoids shown). The hydrogen atoms other than those participating in hydrogen bonding are omitted for clarity. Symmetry code: (iii) $-\mathrm{x},-\mathrm{y}+1,-\mathrm{z}+1$ (iv) $-\mathrm{x}+1,-\mathrm{y},-\mathrm{z}$.

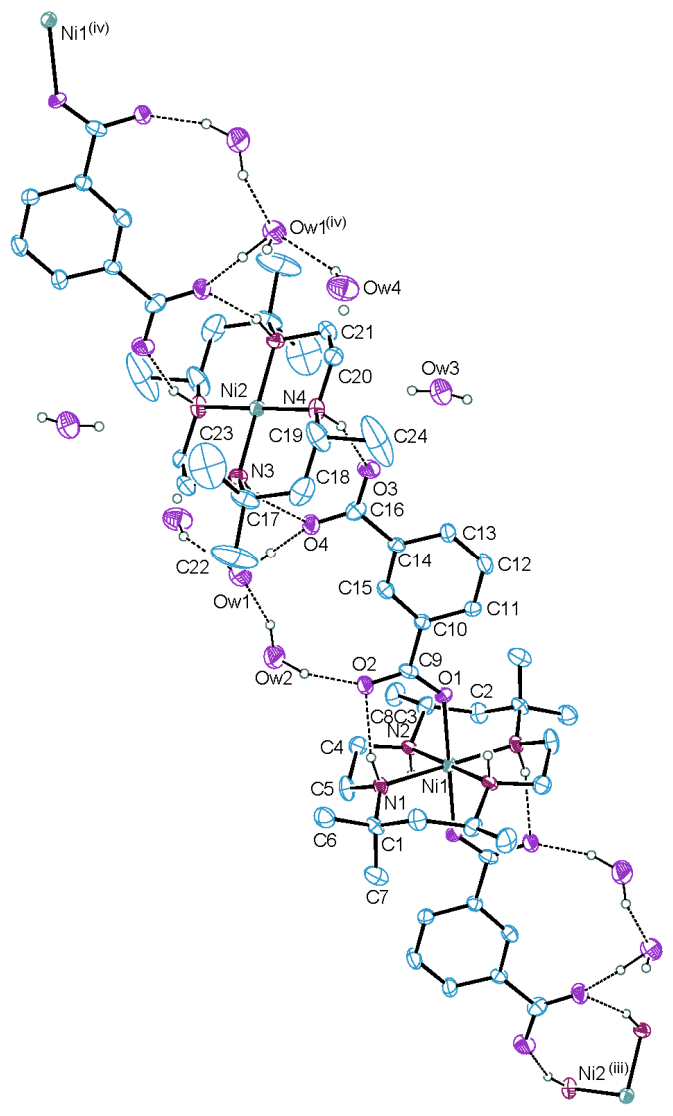

Table 1. Selected bond lengths $(\AA)$ and angles $\left(^{\circ}\right)$.

\begin{tabular}{cccc}
\hline \multicolumn{5}{c}{ Bond lengths and angles } \\
\hline \multicolumn{5}{c}{ Bond lengths } & $\mathrm{Ni}(1)-\mathrm{N}(2)$ & $2.009(7)$ \\
$\mathrm{Ni}(1)-\mathrm{N}(1)$ & $2.130(7)$ & $\mathrm{Ni}(2)-\mathrm{N}(3)$ & $1.913(7)$ \\
$\mathrm{Ni}(1)-\mathrm{O}(1)$ & $2.056(6)$ & $\mathrm{C}(9)-\mathrm{O}(1)$ & $1.254(11)$ \\
$\mathrm{Ni}(2)-\mathrm{N}(4)$ & $1.878(8)$ & $\mathrm{C}(16)-\mathrm{O}(3)$ & $1.196(12)$ \\
$\mathrm{C}(9)-\mathrm{O}(1)$ & $1.238(11)$ & $\mathrm{Ni}(1) \cdots \mathrm{Ni}(2)$ & $11.641(8)$ \\
$\mathrm{C}(16)-\mathrm{O}(4)$ & $1.239(12)$ & & \\
$\mathrm{Ni}(1) \cdots \mathrm{Ni}(2)^{\mathrm{i}}$ & $9.607(4)$ & $\mathrm{N}(1)-\mathrm{Ni}(1)-\mathrm{N}(2)^{\mathrm{iii}}$ & \\
\hline Bond angles & & $\mathrm{N}(1)^{\mathrm{iii}}-\mathrm{Ni}(1)-\mathrm{O}(1)$ & $93.0(3)$ \\
$\mathrm{N}(1)-\mathrm{Ni}(1)-\mathrm{N}(2)$ & $87.0(3)$ & $\mathrm{N}(2)^{\mathrm{iii}}-\mathrm{Ni}(1)-\mathrm{O}(1)$ & $94.4(3)$ \\
$\mathrm{N}(1)-\mathrm{Ni}(1)-\mathrm{O}(1)$ & $89.7(3)$ & $\mathrm{N}(3)-\mathrm{Ni}(2)-\mathrm{N}(4)^{\mathrm{iv}}$ & $88.7(4)$ \\
$\mathrm{N}(2)-\mathrm{Ni}(1)-\mathrm{O}(1)$ & $85.6(3)$ & $\mathrm{O}(1)-\mathrm{C}(9)-\mathrm{O}(2)$ & $127.7(8)$ \\
$\mathrm{N}(3)-\mathrm{Ni}(2)-\mathrm{N}(4)$ & $91.3(4)$ & & \\
$\mathrm{Ni}(1)-\mathrm{O}(1)-\mathrm{C}(9)$ & $133.7(6)$ & $122.6(9)$ & \\
$\mathrm{O}(3)-\mathrm{C}(16)-\mathrm{O}(4)$ & & & \\
\hline
\end{tabular}


Table 2. Hydrogen bonding parameters $\left(\AA,^{\circ}\right)$.

\begin{tabular}{lllll}
\hline $\mathbf{D}-\mathbf{H}^{\cdots} \mathbf{A}$ & $\mathbf{D}-\mathbf{H}(\AA)$ & $\mathbf{H}^{\cdots} \mathbf{A} \mathbf{A}(\mathbf{\AA})$ & $\mathbf{D} \cdots \mathbf{A}(\AA)$ & $\mathbf{D}-\mathbf{H}^{\cdots} \mathbf{A} \mathbf{A}\left({ }^{\circ}\right)$ \\
\hline $\mathrm{N}(1)-\mathrm{H}(1) \cdots \mathrm{O}(2)^{\mathrm{iii}}$ & 0.91 & 1.95 & $2.804(10)$ & 154.6 \\
$\mathrm{~N}(3)-\mathrm{H}(3) \cdots \mathrm{O}(4)$ & 0.91 & 1.98 & $2.869(10)$ & 164.0 \\
$\mathrm{~N}(4)-\mathrm{H}(4) \cdots \mathrm{O}(3)$ & 0.91 & 1.98 & $2.841(11)$ & 157.8 \\
$\mathrm{Ow}(1)-\mathrm{HO}(1) \cdots \mathrm{O}(4)$ & $1.07(10)$ & $1.65(11)$ & $2.676(11)$ & $160(9)$ \\
$\mathrm{Ow}(2)-\mathrm{HO}(3) \cdots \mathrm{O}(2)$ & $1.00(11)$ & $1.76(11)$ & $2.734(12)$ & $163(9)$ \\
$\mathrm{Ow}(2)-\mathrm{HO}(4) \cdots \mathrm{Ow}(1)$ & $0.89(13)$ & $1.92(13)$ & $2.706(14)$ & $147(11)$ \\
$\mathrm{Ow}(4)-\mathrm{HO}(8) \cdots \mathrm{Ow}(1)^{\mathrm{iv}}$ & $0.82(13)$ & $2.12(14)$ & $2.829(17)$ & $145(13)$ \\
\hline
\end{tabular}

Symmetry codes: ${ }^{\text {iii }}-\mathrm{x},-\mathrm{y}+1,-\mathrm{z}+1 ;{ }^{\mathrm{vi}}-\mathrm{x}+1,-\mathrm{y},-\mathrm{z}$.

Figure 3. Crystal packing diagram of $\left[\mathrm{Ni}(\mathrm{L})(\text { isoph })_{2}\right][\mathrm{Ni}(\mathrm{L})] \cdot 8 \mathrm{H}_{2} \mathrm{O}$ (1), showing the intermolecular hydrogen bonds as dashed lines. The hydrogen atoms other than those participating in hydrogen bonding are omitted for clarity.

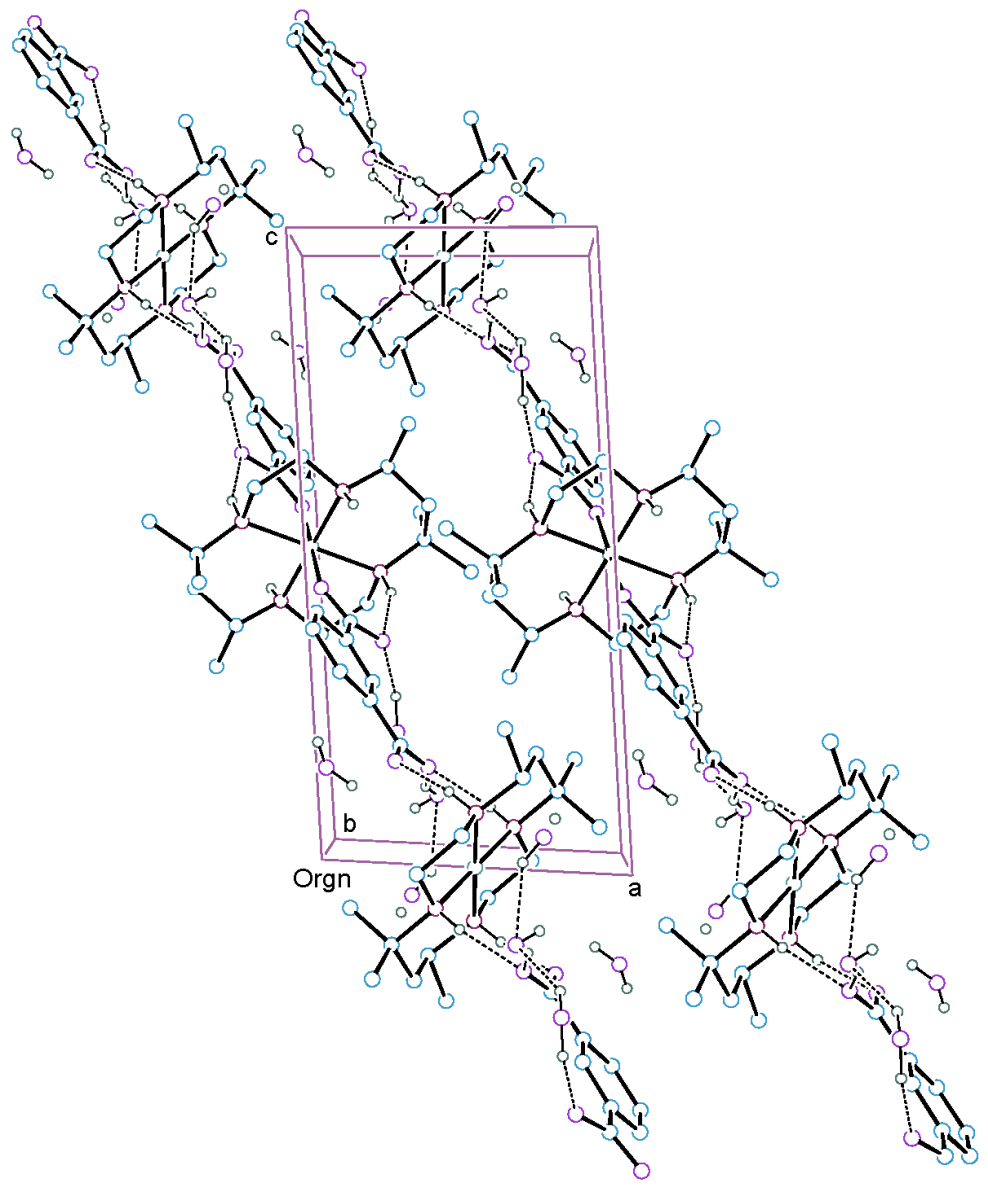

\subsection{Chemical Properties}

The IR spectrum of 1 shows a band at $3148 \mathrm{~cm}^{-1}$ corresponding to the $v(\mathrm{NH})$ of the coordinated secondary amines of the macrocycle. Two strong bands exhibit $v_{a s}(\mathrm{COO})$ stretching frequency at $1606 \mathrm{~cm}^{-1}$ and $v_{\mathrm{sym}}(\mathrm{COO})$ at $1357 \mathrm{~cm}^{-1}$, respectively. The value of $\Delta v\left(249 \mathrm{~cm}^{-1}\right)$ indicates that the carboxylate groups are coordinated to the nickel(II) ion only as monodentate ligands [22,23]. In addition, a sharp band at $3420 \mathrm{~cm}^{-1}$ is associated to the $v(\mathrm{OH})$ stretching vibration of the water 
molecule. The UV-Vis spectral data of $\mathbf{1}$ are listed in Table 3. The solid reflectance spectrum of $\mathbf{1}$ is also shown in Figure 4. The UV spectrum of $\mathbf{1}$ in the water solution shows an absorption maximum in the region $260 \mathrm{~nm}$ attributed to a ligand-metal charge transfer associated with the nitrogen and oxygen donors [23]. As shown in Figure 4, the solid state electronic spectrum of $\mathbf{1}$ in the visible region shows three absorption bands at $325(\mathrm{sh}), 474$, and $696 \mathrm{~nm}$ assignable to the ${ }^{3} \mathrm{~B}_{1 \mathrm{~g}} \rightarrow{ }^{3} \mathrm{E}_{\mathrm{g}}\left(\mathrm{T}_{1 \mathrm{~g}}(\mathrm{P})\right)$, ${ }^{1} \mathrm{~B}_{2 \mathrm{~g}} \rightarrow{ }^{1} \mathrm{~B}_{1 \mathrm{~g}}$, ${ }^{3} \mathrm{~B}_{1 \mathrm{~g}} \rightarrow{ }^{3} \mathrm{~B}_{2 \mathrm{~g}}\left(\mathrm{~T}_{2 \mathrm{~g}}(\mathrm{~F})\right)$ transitions [3,24]. The transitions at 325 and $696 \mathrm{~nm}$ arise from the tetragonal complex while the transition at $474 \mathrm{~nm}$ results from the square planar species. However, the visible spectrum of 1 in water solution displays a broad band $458 \mathrm{~nm}$, which has a low-spin $\mathrm{d}^{8}$ nickel(II) ion in a square-planar environment $[\mathrm{Ni}(\mathrm{L})]\left(\mathrm{ClO}_{4}\right)_{2}(463 \mathrm{~nm})$ [5]. This fact can be understood in terms of the decomposition of the hydrogen bonding or the building block in water solution. The electronic spectrum for $\mathbf{1}$ clearly support the structure determined by the X-ray diffraction study.

Table 3. Electronic spectral data ${ }^{\mathrm{a}}$.

\begin{tabular}{ccc}
\hline Complex & State & $\lambda_{\max } / \mathbf{n m}\left(\boldsymbol{\varepsilon} / \mathbf{M}^{-\mathbf{1}} \mathbf{c m}^{\mathbf{- 1}}\right)$ \\
\hline$[\mathrm{Ni}(\mathrm{L})]\left(\mathrm{ClO}_{4}\right)_{2}{ }^{\mathrm{b}}$ & $\mathrm{H}_{2} \mathrm{O}$ & $463(80)$ \\
& $\mathrm{CH}_{3} \mathrm{CN}$ & $469(63)$ \\
& $\mathrm{Solid}$ & 262,468 \\
\hline$\left[\mathrm{Ni}(\mathrm{L})(\text { isoph })_{2}\right][\mathrm{Ni}(\mathrm{L})] \cdot 8 \mathrm{H}_{2} \mathrm{O}(\mathbf{1})$ & $\mathrm{H}_{2} \mathrm{O}$ & $260\left(5.2 \times 10^{3}\right), 458(71)$ \\
& $\mathrm{Solid}$ & $325(\mathrm{sh}), 474,696$ \\
\hline
\end{tabular}

${ }^{\mathrm{a}}$ Solution $=\mathrm{H}_{2} \mathrm{O}$ at $20 \pm 0.1{ }^{\circ} \mathrm{C}$; Solid $=$ diffuse reflectance; ${ }^{\mathrm{b}}$ Ref. [5].

Figure 4. Solid state electronic absorption spectrum of $\left[\mathrm{Ni}(\mathrm{L})(\text { isoph })_{2}\right][\mathrm{Ni}(\mathrm{L})] \cdot 8 \mathrm{H}_{2} \mathrm{O}(\mathbf{1})$ by the diffuse reflectance method at $20.0 \pm 0.1^{\circ} \mathrm{C}$.

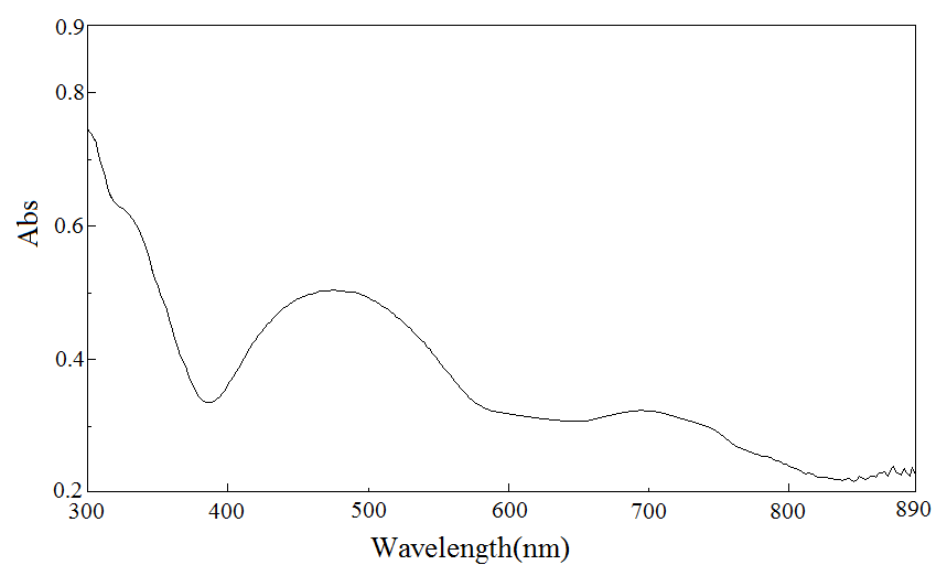

Cyclic voltammetric data for $\mathbf{1}$ in $0.10 \mathrm{M}$ TEAP-DMSO solution are given in Table 4. Cyclic voltammogram of 1 in $0.1 \mathrm{M}$ TEAP-DMSO solution is shown in Figure 5. The $\mathrm{H}_{2}$-isoph ligand is electrochemically active in the range of potential studied. Cyclic voltammetry of $\mathrm{H}_{2}$-isoph shows two irreversible one-electron reductions at -1.33 and $-1.61 \mathrm{~V}$ vs. the $\mathrm{Ag} / \mathrm{AgCl}$ reference electrode. The reduction potential for 1 gives the irreversible one-electron process at $-0.76 \mathrm{~V}$ vs. the $\mathrm{Ag} / \mathrm{AgCl}$ refernce electrode, assigned to the $\mathrm{Ni}^{\mathrm{II}} / \mathrm{Ni}^{\mathrm{I}}$ process. The reduction potentials for $\mathbf{1}$ are considerably more positive than that for the square-planar $[\mathrm{Ni}(\mathrm{L})]\left(\mathrm{ClO}_{4}\right)_{2}(-1.29 \mathrm{~V})[5]$. This fact may be due to the coordination of the axial isoph ${ }^{2-}$ ligand, which is in agreement with the crystal structure of $\mathbf{1}$. 
Table 4. Cyclic voltametric data ${ }^{\mathrm{a}}$.

\begin{tabular}{cc}
\hline Complex & Potentials(V) Ag/AgCl \\
\cline { 2 - 2 } & $\mathbf{N i ( I I ) / N i ( I ) ~}$ \\
\hline$[\mathrm{Ni}(\mathrm{L})]\left(\mathrm{ClO}_{4}\right)_{2}{ }^{\text {b,a }}$ & -1.29 \\
$\frac{\left[\mathrm{Ni}(\mathrm{L})(\text { isoph })_{2}\right][\mathrm{Ni}(\mathrm{L})] \cdot 8 \mathrm{H}_{2} \mathrm{O}(\mathbf{1})}{{ }^{\mathrm{a}} \text { Measured in } 0.10 \mathrm{M} \mathrm{TEAP}-\mathrm{DMSO} \text { solution at } 20.0 \pm 0.1^{\circ} \mathrm{C} ;{ }^{\mathrm{b}} \text { Ref. }[5]{ }^{\mathrm{c}}{ }^{\mathrm{c}} \mathrm{i}=\text { irreversible. }}$
\end{tabular}

Figure 5. Cyclic voltammograms of $[\mathrm{Ni}(\mathrm{L})]\left(\mathrm{ClO}_{4}\right)_{2}$ and $\left[\mathrm{Ni}(\mathrm{L})(\text { isoph })_{2}\right][\mathrm{Ni}(\mathrm{L})] \cdot 8 \mathrm{H}_{2} \mathrm{O}$ (1) in $0.1 \mathrm{M}$ TEAP-DMSO solution at $20.0 \pm 0.1^{\circ} \mathrm{C}$. The scan rate is $100 \mathrm{mV} / \mathrm{s}$.

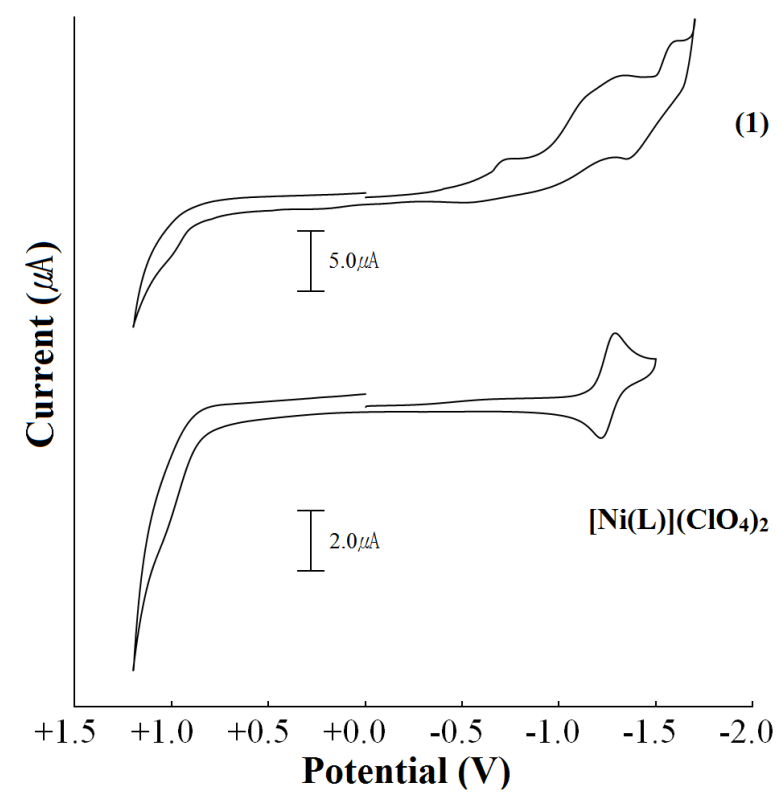

The TGA diagram of $\mathbf{1}$ is shown in Figure 6. The compound was heated in the temperature range $50-1,000{ }^{\circ} \mathrm{C}$ in nitrogen gas. The first weight loss is observed from 30 to $139{ }^{\circ} \mathrm{C}$, which is due to the loss of six water molecules (observed $8.1 \%$, calculated 9.3\%).

Figure 6. Thermogravimetric curve of $\left[\mathrm{Ni}(\mathrm{L})(\text { isoph })_{2}\right][\mathrm{Ni}(\mathrm{L})] \cdot 8 \mathrm{H}_{2} \mathrm{O}(\mathbf{1})$.

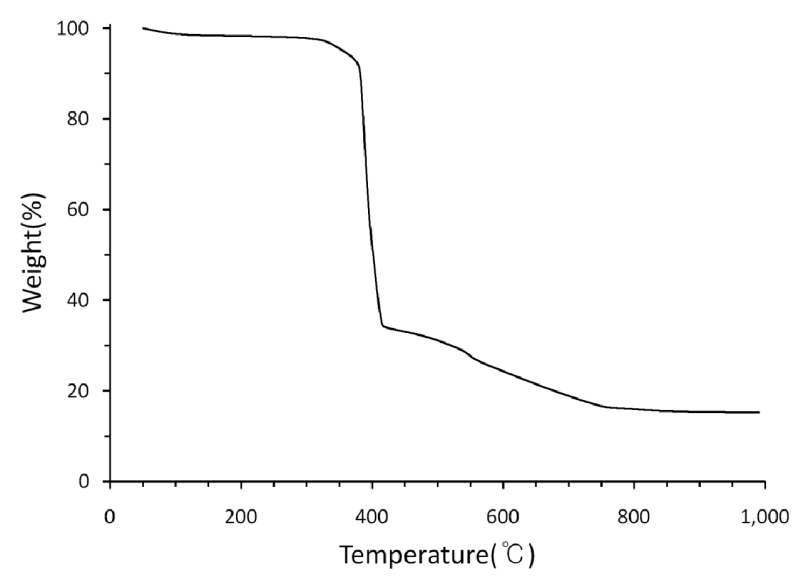

A second weight loss corresponding to the macrocycle (observed 51.8\%, calculated $49.1 \%$ ) is found in the temperature range $382-405{ }^{\circ} \mathrm{C}$. On further heating, 1 lost weight between 405 and $756{ }^{\circ} \mathrm{C}$ 
corresponding to two isophthalate ligands (observed 26.7\%, calculated 28.3\%). Further weigh loss is not observed in the temperature range 756 to $1000{ }^{\circ} \mathrm{C}$ corresponding to the greenish black residue of $\mathrm{NiO}$ (observed 13.3\%, calculated 12.9\%).

\section{Experimental}

\subsection{Materials and Physical Measurements}

The chemicals and solvent $\mathrm{NiCl}_{2} \cdot 6 \mathrm{H}_{2} \mathrm{O}$ (99.99\%), isophthalic acid (99\%), and acetonitrile (99.93\%) were purchased from Aldrich (Milwaukee, WI, USA) and used without futher purification. The C-meso-5,5,7,12,12,14-hexamethyl-1,4,8,11-tetraazacyclotetradecane ligand (L) was prepared according to literature method [4,5]. IR spectra were recorded with a Jasco FT/IR-4100 spectrophotometer using $\mathrm{KBr}$ pellets. Electrochemical measurements were accomplished with a three electrode potentiostat BAS-100BW system. A 3-mm Pt disk was used as the working electrode. The counter electrode was a coiled $\mathrm{Pt}$ wire and an $\mathrm{Ag} / \mathrm{AgCl}$ electrode was used as a reference electrode. Cyclic voltammetric data were obtained in DMSO solution using $0.10 \mathrm{M}$ tetraethylammonium perchlorate (TEAP) as supporting electrolyte at $20.0 \pm 0.1{ }^{\circ} \mathrm{C}$. The solution was degassed with high purity $\mathrm{N}_{2}$ prior to carrying out the electrochemical measurements. The DSC and TGA were performed under flowing nitrogen at a heating rate of $10{ }^{\circ} \mathrm{C} \mathrm{mim}^{-1}$ using a SDT 2960 Thermogravimetric Analyzer. Elemental analyses $(\mathrm{C}, \mathrm{H}, \mathrm{N})$ were performed on a Perkin-Elmer CHN-2400 analyzer.

\subsection{Synthesis of $\left[\mathrm{Ni}(\mathrm{L})(\text { isoph })_{2}\right][\mathrm{Ni}(\mathrm{L})] \cdot 8 \mathrm{H}_{2} \mathrm{O}(\mathbf{1})$}

To a methanol solution of $(20 \mathrm{~mL})$ of $\mathrm{NiCl}_{2} \cdot 6 \mathrm{H}_{2} \mathrm{O}(119 \mathrm{mg}, 0.5 \mathrm{mmol})$ was added $\mathbf{L}(142 \mathrm{mg}$, $0.5 \mathrm{mmol})$ and sodium isophthalate $\left(\mathrm{Na}_{2}\right.$ isoph $)(105 \mathrm{mg}, 0.5 \mathrm{mmol})$ and the mixture was stirred for 1 $\mathrm{hr}$ at room temperature. The solution was filtered and left at room temperature until the violet crystals formed. The product was recrystallized from a hot water/acetonitrile $(1: 1 \mathrm{v} / \mathrm{v}, 10 \mathrm{~mL})$ mixture. Yield: 56\%. Calc. (found) for $\mathrm{C}_{48} \mathrm{H}_{96} \mathrm{~N}_{8} \mathrm{Ni}_{2} \mathrm{O}_{16}$ : C, 49.76 (49.62); H, 8.35 (8.46); N, 9.67 (9.75)\%. IR (KBr, $\mathrm{cm}^{-1}$ ): 3,420 (s), $3269(\mathrm{~m}), 3,148(\mathrm{~m}), 3,068(\mathrm{~m}), 2,962(\mathrm{~m}), 1,606(\mathrm{~s}), 1,561(\mathrm{~s}), 1,460(\mathrm{w}), 1,422(\mathrm{w})$, 1,373 (s), 1,357 (s), 1,304 (w), 1,274 (w), 1,186 (m), 1,156 (m), 1,095 (m), 1,073 (m), 1,053 (m), 997 (w), $958(\mathrm{w}), 928(\mathrm{w}), 810(\mathrm{w}), 743(\mathrm{~m}), 710(\mathrm{~m}), 692(\mathrm{w}), 641(\mathrm{w})$.

\subsection{X-ray Crystallography}

Single crystal X-ray diffraction measurement for 1 was carried out on an Enraf-Nonius CAD4 diffractometer using graphite-monochromated Mo-Ka radiation $(\lambda=0.71073 \AA)$. Intensity data were measured at 293(2) K by $\omega-2 \theta$ technique. Accurate cell parameters and an orientation matrix were determined by the least-squares fit of 25 reflections. The intensity data were corrected for Lorentz and polarization effects. Empirical absorption correction was carried out using $\psi$-scan [25]. The structure was solved by direct methods and the least-squares refinement of the structure was performed by the SHELXL-97 program [26]. All the non-hydrogen atoms were refinded anisotropically. The hydrogen atoms were placed in calculated positions, allowing them to ride on their parent $\mathrm{C}$ and $\mathrm{N}$ atoms with $U_{\text {iso }}(\mathrm{H})=1.2 U_{\text {eq }}(\mathrm{C}$ or $\mathrm{N})$. A summary of the data collections and details of the structure refinement is given in Table 5 . 
Crystallographic data for the structural analysis have been deposited with the Cambridge Crystallographic Data Center, CCDC No. 846954 for 1. Copies of this information may be obtained free of charge from the Director, CCDC, 12 Union Road, Cambridge, CB2, 1EZ, UK (fax: +44-1223336033; e-mail: deposit@ccdc.cam.uk or http://www.ccdc.cam.ac.uk).

Table 5. Crystallographic data.

\begin{tabular}{|c|c|}
\hline \multicolumn{2}{|c|}{ Data and refinement } \\
\hline Empirical formula & $\mathrm{C}_{48} \mathrm{H}_{96} \mathrm{~N}_{8} \mathrm{Ni}_{2} \mathrm{O}_{16}$ \\
\hline Formula weight & 1157.94 \\
\hline Temperature (K) & 293(2) \\
\hline Crystal color/habit & Brown/prism \\
\hline Crystal system & Triclinic \\
\hline Space group & $P-1$ \\
\hline \multicolumn{2}{|l|}{ Unit cell dimensions } \\
\hline$a(\AA)$ & $8.602(2)$ \\
\hline$b(\AA)$ & $10.684(7)$ \\
\hline$c(\AA)$ & $16.550(3)$ \\
\hline$\alpha\left(^{\circ}\right)$ & $91.04(4)$ \\
\hline$\beta\left(^{\circ}\right)$ & $94.09(2)$ \\
\hline$\gamma\left({ }^{\circ}\right)$ & $111.09(4)$ \\
\hline$V\left(\AA^{3}\right)$ & $1413.9(10)$ \\
\hline$Z$ & 1 \\
\hline$D_{\text {calc }}\left(\mathrm{Mg} \mathrm{m}^{-3}\right)$ & 1.360 \\
\hline Absorption coefficient $\left(\mathrm{mm}^{-1}\right)$ & 0.738 \\
\hline$F(000)$ & 624 \\
\hline Crystal size $\left(\mathrm{mm}^{3}\right)$ & $0.40 \times 0.30 \times 0.10$ \\
\hline$\theta$ range $\left(^{\circ}\right)$ & 1.23 to 26.37 \\
\hline Limiting indices & $-10 \leq h \leq 10,-13 \leq k \leq 13,-1 \leq l \leq 19$ \\
\hline Reflection collected/unique & $5729 / 5137\left(R_{\text {int }}=0.0817\right)$ \\
\hline Absorption correction & $\psi$-scan \\
\hline Max./min. transmission & 0.9145 and 0.7122 \\
\hline Data/restraints/parameters & $5137 / 0 / 369$ \\
\hline Goodness of fit on $F^{2}$ & 1.184 \\
\hline Final $R$ indices $(I>2 \sigma(I))$ & $R_{1}^{\mathrm{a}}=0.0811, w R_{2}^{\mathrm{b}}=0.2224$ \\
\hline$R$ indices (all data) & $R_{1}=0.1742, w R_{2}=0.3391$ \\
\hline Weighting scheme & $w=1 /\left[\sigma^{2}\left(F_{\mathrm{o}}^{2}\right)+(0.20000 P)^{2}\right.$ \\
\hline & $+0.0000 P]$ \\
\hline Largest difference peak and hole & with $P=\left(F_{\mathrm{o}}^{2}+2 F_{\mathrm{c}}^{2}\right) / 3$ \\
\hline$\left(\mathrm{e} \AA^{-3}\right)$ & 1.731 and -1.199 \\
\hline
\end{tabular}

\section{Conclusions}

Complex 1 reveals a geometrically symmetric core with a $\{4 / 6\}$ coordination number set. The coordination environment around the $\mathrm{Ni}(1)$ ion is a distorted octahedron, while the geometry around the four-coordinate $\mathrm{Ni}(2)$ is depicted as square planar in 1D hydrogen-bonded infinite chain. The solid 
state electronic spectrum of $\mathbf{1}$ in the visible region shows three absorption bands assignable to the tetragonal and the square planar species. The cyclic voltammogram of $\mathbf{1}$ displays a one-electron wave corresponding to the $\mathrm{Ni}^{\mathrm{II}} / \mathrm{Ni}^{\mathrm{I}}$ redox process. The reduction potentials for $\mathbf{1}$ are considerably more positive than that for the square-planar $[\mathrm{Ni}(\mathrm{L})]\left(\mathrm{ClO}_{4}\right)_{2}$. The TGA behavior of the complex $\mathbf{1}$ is significantly affected by the nature of the hexamethyltetraaza macrocycle and the axial isoph ${ }^{2-}$ ligand.

\section{Supplementary Materials}

Supplementary materials can be accessed at: http://www.mdpi.com/1420-3049/18/6/6608/s1.

\section{Conflict of Interest}

The authors declare no conflict of interest.

\section{References}

1. Hay, R.W.; Pujari, M.P. The preparation of cis-folded macrocyclic nickel(II) complexes and the kinetics of their base-catalysed conversion to planar species. J. Chem. Soc. Dalton Trans. 1986, 1485-1489.

2. Black, D.G.; Jordan, R.F.; Rogers, R.D. Structural Trends in Group 4 Metal Tetraaza Macrocycle Complexes. Molecular Structures of $\left(\mathrm{Me}_{4}\right.$ taen $) \mathrm{Zr}\left(\mathrm{O}^{t} \mathrm{Bu}\right)_{2}$ and $\left(\mathrm{Me}_{4}\right.$ taen $) \mathrm{Hf}\left(\mathrm{NMe}_{2}\right)_{2}$. Inorg. Chem. 1997, 36, 103-108.

3. Misra, T.K.; Chung, C.S.; Cheng, J.; Lu, T.H. Isolation and structural characterization of trans- $\beta$ $\{(C$-meso-5,5,7,12,12,14-hexamethyl-1,4,8,11-tetraazacyclotetradecane)(diaquo) $\}$ nickel(II) perchlorate and cis- $\alpha$ - $\{(C$-racemic-5,5,7,12,12,14-hexamethyl-1,4,8,11-tetraazacyclotetradecane $)$ (diisothiocyanato) \}nickel(II). Polyhedron 2001, 20, 3149-3154.

4. Curtis, N.F. Some cyclic tetra-amines and their metal-ion complexes. Part I. Two isomeric hexamethyltetra-azacyclotetradecanes and their copper(II) and nickel(II) complexes. J. Chem. Soc. 1964, 2644-2650.

5. Warner, L.G.; Busch, D.H. Stereoisomers of a macrocyclic nickel(II) complex containing six asymmetric centers. Factors determining the stabilities of configurations and conformations. J. Am. Chem. Soc. 1969, 91, 4092-4101.

6. Escuer, A.; Vicente, R.; Salah El Fallah, M.; Solans, X.; Font-Bardia, M. Synthesis, structure and magnetic properties of several nickel-azido complexes with tetraamines as blocking ligands. Inorg. Chim. Acta 1996, 247, 85-91.

7. Escuer, A.; Vicente, R.; Ribas, J.; Salah J Fallah, M.; Solans, X. The first 1D nickel(II) complex with a single azido bridge: structure and magnetic behavior of catena- $\left(\mu-\mathrm{N}_{3}\right)[\mathrm{Ni}(1,4,8,11$ tetraazacyclotetradecane) $]\left(\mathrm{ClO}_{4}\right) \cdot \mathrm{H}_{2} \mathrm{O}$. Inorg. Chem. 1993, 32, 1033-1035.

8. Vicente, R.; Escuer, A.; Salah El Fallah, M.; Solans, X.; Font-Bardia, M. Three new mononuclear nickel(II) cyanate and isocyanate compounds derived from macrocyclic ligands: [Ni(TMCY) $(\mathrm{NCO})]\left(\mathrm{ClO}_{4}\right),\left[\mathrm{Ni}(m-\mathrm{CTH})(\mathrm{OCN})_{1.5}\left(\mathrm{ClO}_{4}\right)_{0.5}\right]$. Inorg. Chim. Acta 1997, 261, 227-237.

9. Choi, K.Y.; Kim, Y.J.; Ryu, H.; Suh, I.H. Synthesis and characterization of nickel(II) complexes of a tetraaza macrocycle containing axial ligands. Inorg. Chem. Commun. 1999, 2, 176-180. 
10. Escuer, A.; Vicente, R.; Salah El Fallah, M.; Solans, X.; Font-Bardia, M. Structure and magnetic behaviour of the first singly bridged nickel cyanate chain and a new dinuclear complex: an approximation to the superexchange mechanism for the nickel pseudohalide system. J. Chem. Soc. Dalton Trans. 1996, 1013-1019.

11. Escuer, A.; Vicente, R.; Salah El Fallah, M.; Ribas, J.; Solans, X.; Font-Bardia, M. Unusual magnetic and structural one-dimensional nickel(II) azido systems. J. Chem. Soc. Dalton Trans. 1993, 2975-2976.

12. Hay, R.W.; Jeragh, B.; Ferguson, G.; Kaither, B.; Ruhl, B.L. Axial additions in nickel(II) complexes of $(5 S R, 7 R S, 12 R S, 14 S R)$-tetra-methyl-1,4,8,11-tetra-azacyclotetradecane $\left(\mathrm{L}_{\alpha}\right)$ and crystal-structure analysis of the planar orange and octahedral violet perchlorate salts $\mathrm{NiL}_{\alpha},\left(\mathrm{ClO}_{4}\right)_{2}$. J. Chem. Soc. Dalton Trans. 1982, 1531-1539.

13. Hay, R.W.; Danby, A.; Lighfoot, P.; Lampeka, Y.D. Padlock macrocyclic complexes. The synthesis of a range of nickel(II) complexes of $N$-alkyl azacyclams and the crystal structure of (3ethyl-1,3,5,8,12-penta-azacyclotetradecane) nickel(II) perchlorate. Polyhedron 1997, 16, 2777-2783.

14. Hay, R.W.; Crayston, J.A.; Cromie, T.J.; Lighfoot, P.; de Alwis, D.C.L. The preparation, chemistry and crystal structure of the nickel(II) complex of N-hydroxyethylazacyclam [3-(2'hydoxyethyl)-1,3,5,8,12-pentaazacyclotetradecane nickel(II) perchlorate]. A new electrocatalyst for $\mathrm{CO}_{2}$ reduction. Polyhedron 1997, 16, 3557-3563.

15. Choi, K.Y.; Kim, J.C.; Jensen, W.P.; Suh, I.H.; Choi, S.-S. Copper(II) and Nickel(II) Complexes with 3,14-Dimethyl-2,6,13,17-tetraazatricyclo[16.4.0.0 $\left.0^{7,12}\right]$ docosane, $\left[M\left(\mathrm{C}_{20} \mathrm{H}_{40} \mathrm{~N}_{4}\right)\right] \mathrm{Cl}_{2} \cdot 2 \mathrm{H}_{2} \mathrm{O}$ $\left(M=\mathrm{Cu}^{\mathrm{II}}\right.$ and $\left.\mathrm{Ni}^{\mathrm{II}}\right)$. Acta Crystallogr. 1996, C52, 2166-2168.

16. Curtis, N.F.; Wikaira, J. Nickel(II) compounds of a tri-amine mono-imine macrocycle: Preparations and structures of (5,7,7,12,14,14-hexamethyl-1,4,8,11-tetraazacyclotetradec-4ene)nickel(II) compounds. Polyhedron 2011, 30, 895-902.

17. Choi, K.Y.; Chun, K.M.; Suh, I.H. Synthesis and characterization of one-dimensional nickel(II) macrocyclic complexes with bridging organic ligands. Polyhedron 2001, 20, 57-65.

18. Choi K.Y.; Kim, K.J. Self-assembly of 1D coordination polymers from nickel(II) tetraaza macrocycle and carboxylate ligands. Polyhedron 2008, 27, 1310-1316.

19. Fenton, D.D.; Okawa, H. Dalton perspective. The emergence of trinuclear constellations at metallobiosites. J. Chem. Soc. Dalton Trans. 1993, 1349-1357.

20. Tsukube, H.; Yoden, T.; Iwachido, T.; Zenki, M. Lipid-bound macrocycles as new immobilized ligand systems for effective separation of metal cations. J. Chem. Soc. Chem. Commun. 1991, 1069-1070.

21. Farrugia, L.J. ORTEP-3 for windows - a version of ORTEP-III with a graphical user interface (GUI). J. Appl. Crystallogr. 1997, 30, 565.

22. Bakalbassis, E.G.; Tsipis, C.A.; Bozopoulos, A.P.; Dreissing, D.W.; Hartl, H.; Mrozinski, J. Strong ferromagnetism between copper(II) ions separated by 6.7.ANG. in a new phthalatobridged copper(II) binuclear complex. Inorg. Chem. 1991, 30, 2801-2806.

23. Cao, R.; Shi, Q.; Sun, D.; Hong, M.; Bi, W.; Zhao, Y. Syntheses and characterizations of copper(II) polymeric complexes constructed from 1,2,4,5-benzenetetracarboxylic acid. Inorg. Chem. 2002, 41, 6161-6168. 
24. Vigee, G.S.; Watkins, C.L.; Bowen, H.F. The chemical dynamics of 1,4,8,11-tetraazacyclotetradecane nickel(II) perchlorate with several solvents. I. Thermodynamics of base adduct formation. Inorg. Chim. Acta 1979, 35, 255-259.

25. North, A.C.T.; Phillips, D.C; Mathews, F.S. A semi-empirical method of absorption correction. Acta Crystallogr. 1968, A24, 351-359.

26. Sheldrick, G.M. A short history of SHELX. Acta Crystallogr. 2008, A64, 112-122.

Sample Availability: Sample of the $\left[\mathrm{Ni}(\mathrm{L})(\mathrm{isoph})_{2}\right][\mathrm{Ni}(\mathrm{L})] \cdot 8 \mathrm{H}_{2} \mathrm{O}$ is available from the authors.

(C) 2013 by the authors; licensee MDPI, Basel, Switzerland. This article is an open access article distributed under the terms and conditions of the Creative Commons Attribution license (http://creativecommons.org/licenses/by/3.0/). 